\title{
Comparison of the Influencing Factors of International Competitiveness between China and India Manufacturing Industries
}

\author{
Meijuan Li ${ }^{\mathrm{a}}$, Yumei Zhang ${ }^{\mathrm{b}}$

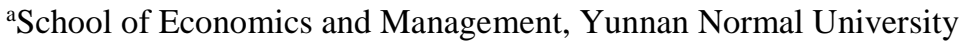 \\ Kunming and 650500, China \\ ${ }^{\mathrm{b}}$ School of Economics and Management, Yunnan Normal University \\ Kunming and 650500, China
}

\begin{abstract}
This paper focuses on the international competitiveness of the manufacturing industries of China and India. Starting from the status quo of the development of the manufacturing industries in both countries, this paper compares and analyzes the influencing factors of international competitiveness. The results show that, the differences between the two countries in advanced production factors are relatively large, but they are similar in basic production factors. For the personnel and knowledge resources, China has a comparative outstanding advantage in terms of higher education enrollment rate, research expenditure, and number of patent applications compared to India. For the labor costs, India's manufacturing costs are more advantageous than that of China. For the capital resources, although India has continuously improved its ability to attract foreign investment in recent years, it is inferior to China. The development of manufacturing can not be separated from the support of related industries. The Indian's IT industry gives a lot of support to it's manufacturing industry, China is a logistics industry with more advantages. From the standpoint of the government, China's medical system is developing better, but India is lenient on taxation. According to the research conclusion, this paper makes corresponding recommendations for the development of China's manufacturing industry.
\end{abstract}

Keywords-China; India; Manufacturing Industry; International Competitiveness

\section{INTRODUCTION}

The level of development of the manufacturing industry directly reflects the level of productivity of a country and determines the international competitiveness of a country and its status in the international division of labor [1]. At present, China is the world's largest manufacturing country, but it is not a manufacturing powerhouse. The level of manufacturing industry is still at the low end. With the development of Southeast Asia manufacturing industry and India's manufacturing industry, the development advantages of
China's manufacturing industry have gradually weakened. In India, along with economic development, policy changes and the shift in manufacturing costs in the world, India's manufacturing industry has developed rapidly; through India's manufacturing industry's total production and development level is still far below China, with a "voice" which India manufacturing industry will catch up China manufacturing industry arise, China has to pay attention to the rise of India's manufacturing industry.

\section{Status OF MANUFACTURING DEVELOPMENT IN CHINA AND INDIA}

\section{A. Status of Export Development}

From Figures 1 and 2, it can be seen that in 2009, China's total exports and total exports of manufacturing industries all fell sharply. This was affected by the US financial crisis in 2008 , but the share of manufacturing in total exports was rising. And, driven by the manufacturing industry, the economy is rapidly recovering and developing rapidly. By 2016, China's total exports reached US\$2199.968billion. The total value of manufacturing exports reached US\$1992.444 billion, and the manufacturing industry account for $93.75 \%$ of the total exports. It can be seen that the development of Indian manufacturing industry is slow, and the export value of manufacturing industry is also relatively low. In 2000, the total export value of India was US\$60.697 billion, and the manufacturing export value was US\$3,003 million. Exports accounted for $77.83 \%$ of total exports of merchandise exports; by 2016 , India's total exports were US\$ 434.116 billion, manufacturing exports were US\$ 19.29 billion, and manufacturing exports accounted for $73.07 \%$ of total exports of merchandise exports. 


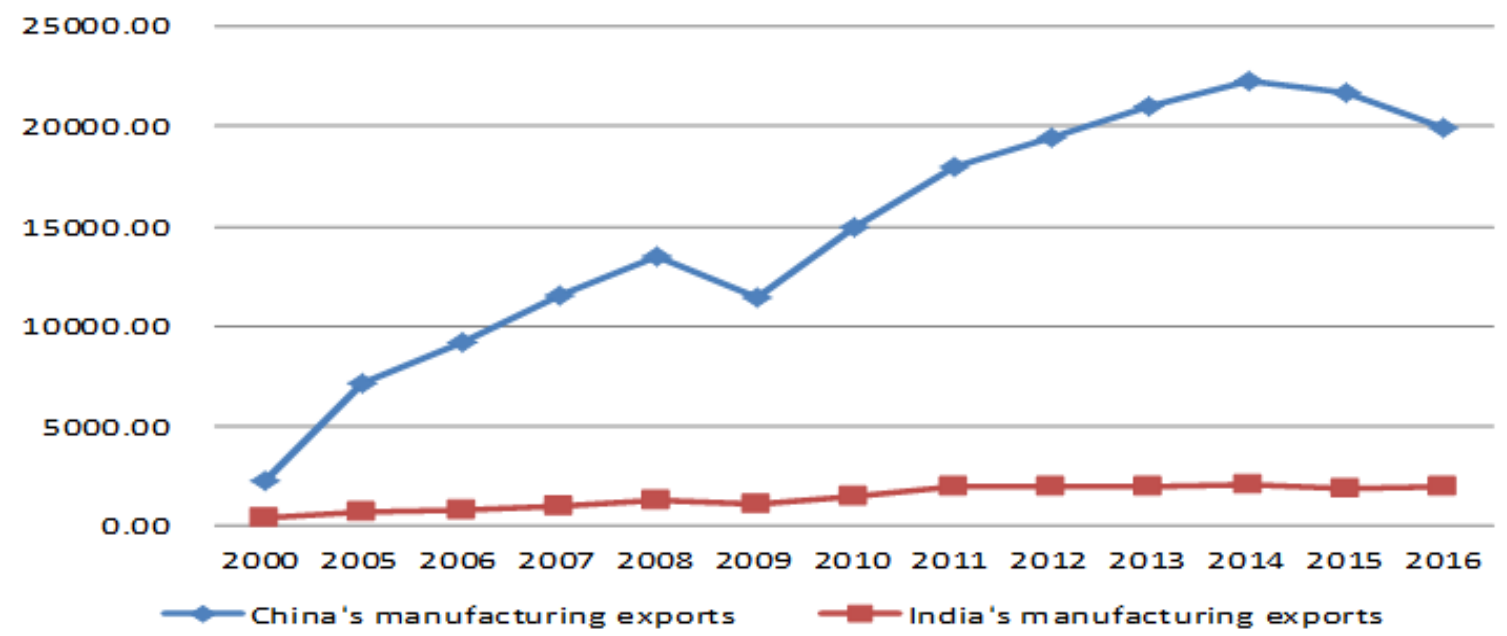

Fig. 1. China-India Manufacturing Exports. Unit: \$100 million

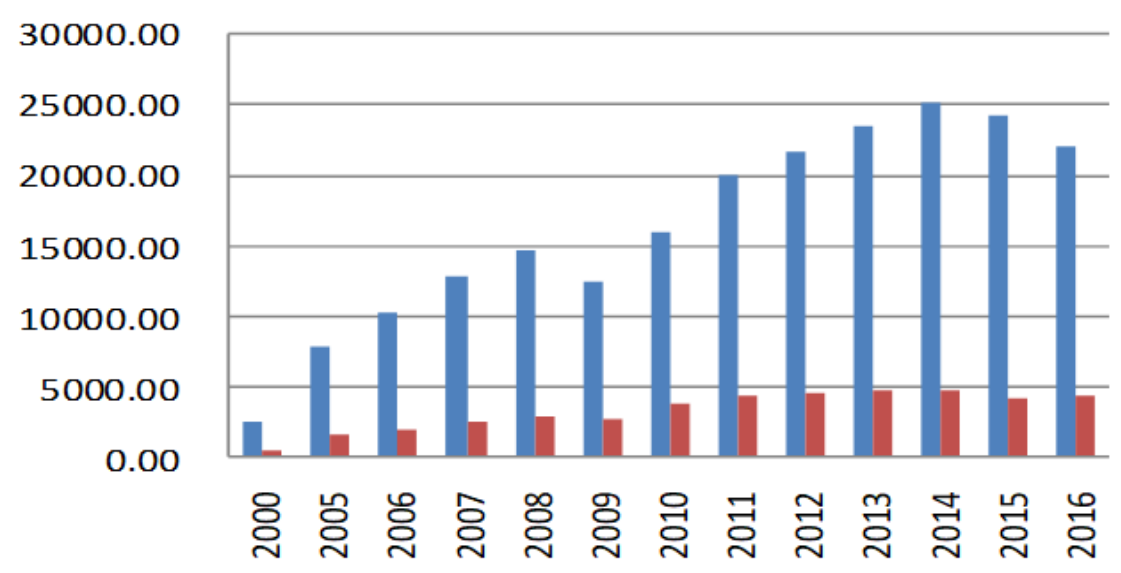

a. Source: International Statistical Yearbook

Fig. 2. Total exports of China and India. Unit: \$100 million

\section{B. Status of Manufacturing Added Value.}

From the data in Table1 In 2007, the added value of China's manufacturing industry was $1,149.72$ billion U.S. dollars, and its annual growth rate reached $16.63 \%$, accounting for $32.36 \%$ of the total GDP. Affected by the economic crisis in 2008 , the total export value of manufacturing industries and the added value of manufacturing industries, the annual growth rate has declined, but in general, the added value of the manufacturing industry has grown, and the proportion of the added value of the manufacturing industry in GDP has not changed much. After 2008, although the annual growth rate of the added value of the manufacturing industry is gradually declining, In general, China's manufacturing industry has maintained steady development.

From the data in Table2, it can be seen that the annual growth rate of the value-added of Indian manufacturing industry in 2006 reached the highest 14.31\%, However, compared with the Chinese manufacturing industry, the added b. Source: https://data.worldbank.org/indicator/BX.GSR.TOTL.CD?locations=CN-IN value of China's manufacturing industry accounts for almost all of GDP. More than 30\%, the added value of manufacturing also far exceeds the added value of Indian manufacturing. In fact, it can also be seen that the development of China's manufacturing industry has better economic policy support and development background. 
TABLE I. CHINA'S VALUE-ADDED OF MANUFACTURING AND ITS SHARE OF GDP

\begin{tabular}{|c|c|c|c|}
\hline Year & $\begin{array}{c}\text { Manufacturin } \\
\text { g added value } \\
(\$ 100 \text { million })\end{array}$ & $\begin{array}{r}\text { Manufacturing value- } \\
\text { added annual growth rate } \\
(\%)\end{array}$ & $\begin{array}{r}\text { Manufacturing value- } \\
\text { added ratio in GDP (\%) }\end{array}$ \\
\hline 2000 & $3,849.37$ & 10.77 & 31.77 \\
\hline 2005 & $7,336.56$ & 9.47 & 32.09 \\
\hline 2008 & $14,756.64$ & 9.39 & 32.09 \\
\hline 2009 & $16,119.46$ & 7.76 & 31.54 \\
\hline 2010 & $19,243.24$ & 13.3 & 31.54 \\
\hline 2014 & $31,842.35$ & 6.9 & 29.37 \\
\hline 2015 & $31,234.41$ & 6.2 & \\
\hline 2016 & $30,798.95$ & 5.9 & \\
\hline
\end{tabular}

TABLE II. INDIA'S VALUE-ADDED OF MANUFACTURING AND ITS SHARE OF GDP FROM 2000 TO 2016

\begin{tabular}{|c|c|c|c|}
\hline Year & $\begin{array}{l}\text { Manufacturing added } \\
\text { value ( } \$ 100 \text { million) }\end{array}$ & $\begin{array}{c}\text { Manufacturing value- } \\
\text { added annual growth rate } \\
(\%)\end{array}$ & $\begin{array}{l}\text { Manufacturing value-added } \\
\text { ratio in GDP (\%) }\end{array}$ \\
\hline 2000 & 764.7 & 7.29 & 18.07 \\
\hline 2005 & $1,343.95$ & 10.10 & 18.16 \\
\hline 2006 & $1,600.2$ & 14.31 & 18.95 \\
\hline 2010 & $2,684.85$ & 8.8 & 17.46 \\
\hline 2014 & $3,081.17$ & 8.25 & 16.41 \\
\hline 2015 & $3,153.91$ & 10.80 & 16.57 \\
\hline 2016 & $3,365.66$ & 7.89 & 16.51 \\
\hline
\end{tabular}

\section{COMPARISON OF THE INFLUENCING FACTORS OF INTERNATIONAL COMPETITIVENESS IN CHINA-INDIA MANUFACTURING}

Michael Porter (M.E.Porter) began to study the national international competitiveness of the industry from the early 1990s and proposed the famous "diamond model." He believes that international competitiveness should be analyzed from the perspective of industry, not from the national point of view [2]. The factors that determine the advantages of a country's international competitiveness in a country are factors of production, demand conditions, industry conditions and corporate strategies under related support, Structure and competition conditions; In Porter's diamond model, Porter believes that factors can be divided into primary production factors and high-level production factors, and is divided into high-level production factors such as senior talents, knowledge resources, and capital resources.

Later, Cho Dong Sung (Cho, D.Sung) proposed a "Ninefactor model" based on the "diamond mode"l. He divided the elements that determine industrial competitiveness into three categories: (1) Objective factors: material resources, business environment, and related Status of the industry and market demand; (2) Main factors: laborers, government workers, entrepreneurs, management experts, and technical experts; (3) External factors: the ability to grasp international competition opportunities [3].

\section{A. Factor of production}

1) Talent and knowledge resources

The number of top 1000 universities in the world in both China and India in 2015 was 83, 16 respectively. Judging from the enrollment ratios of higher education in the two countries, in 2000, the higher enrollment ratio of higher education in India was higher than in China, but from 2000 to 2015, China's higher enrollment ratio for higher education increased rapidly from $7.8 \%$ to $43.4 \%$, while India's only increased from $9.57 \%$ to $26.9 \%$. It is clear that by 2015 , higher education development in China will take precedence over India. 
TABLE III. HighER EDUCATION ROUGH AdMISSION RATE (\%)

\begin{tabular}{|l|l|l|l|l|}
\hline & 2000 & 2005 & 2010 & 2015 \\
\hline China & 7.80 & 19.30 & 25.95 & 43.40 \\
\hline India & 9.57 & 10.7 & 17.87 & 26.9 \\
\hline
\end{tabular}

${ }_{\text {f. }}$ Source:http://data.stats.gov.cn/lastestpub/gjnj/2017/indexeh.htm

\section{2) Labor cost}

The labor force is a key factor in the development of manufacturing. The size of labor costs directly affects the cost of manufacturing production, and it has a great impact on the competitiveness of a country's manufacturing industry [4]. In 2000, the manufacturing costs of the two countries were very close to each other, which was $\$ 0.7$, $\$ 0.9$ per hour. China was slightly lower than India. The average labor cost of the manufacturing industry in 2015 was 18.7 dollars per hour, and manufacturing labor costs in India and China were respectively For 3.3, 1.7 US dollars per hour, China's manufacturing labor costs are twice that of India. For both countries, India have more advantages in this regard [5].

TABLE IV. MANUFACTURING LABOR COST (US DOLLAR PER HOUR)

\begin{tabular}{|l|l|l|}
\hline & 2005 & 2015 \\
\hline China & 0.7 & 3.3 \\
\hline India & 0.9 & 1.7 \\
\hline
\end{tabular}

\section{3) Capital resources}

Generally speaking, a country's GDP is used to measure the size of a country's market. The country with a larger GDP has a stronger potential for spending power and the market is larger. In 2016, China's GDP was \$ 11199.1 billion, and India's was $\$ 2263.79$ billion, which is just one-fifth that of China. In 2016, China's GDP growth rate was $6.69 \%$, and India's was $7.11 \%$. According to the data, China is still a country with a large market size; in 2016, China's foreign exchange reserves stood at $\$ 3010.52$ billion, and India's $\$ 336.58$ billion, which is only one-ninth that of China. From the perspective of attracting foreign investment, in 2016 the Chinese foreign investment net inflow of direct investment was $\$ 170.557$ billion, India was only $\$ 44.459$ billion. China’s have more stronger, ability to attract foreign investment [6].

\section{B. Related industries}

\section{1) Service industry}

The development of the service industry can provide a powerful impetus for the progress of the manufacturing industry ${ }^{[7]}$. The service industry has become the biggest driver of economic growth in India. As far as the IT industry, India's software industry can be said to be outstanding, and Bangalore is also known as the "India's Silicon Valley." The rapid development of the Indian software industry and the
Source:http://data.stats.gov.cn/lastestpub/ginj/2017/indexeh.htm continuous improvement of the financial system have all contributed to the economic development of the region, which has also contributed to the development of the manufacturing industry and enhanced the international competitiveness of the manufacturing industry. Compared with India, although the service industry in China is constantly developing, it is still slightly behind India, which has caused some obstacles to the development of China's manufacturing industry [8].

\section{2) Logistics industry}

An important indicator for measuring logistics capabilities is the logistics performance index. The index ranged from 1 to 5. The higher index data mean a better the performance.

China's logistics performance index has always been higher than that of India. China's logistics performance index has been maintaining a steady growth. In 2016, China's logistics performance index reached 3.66; before 2014, India's logistics performance index was relative low. At around 3.08, but in 2016 India's logistics performance index increased to 3.42. At present, the development of China's express delivery industry is among the highest in the world, and transportation development is also relatively good. Overall, China's development in the logistics industry is more advantageous than India's [9]. 
TABLE V. China AND India Logistics PERFoRmance IndEX

\begin{tabular}{|c|c|c|c|c|c|}
\hline & 2007 & 2010 & 2012 & 2014 & 2016 \\
\hline China & 3.32 & 3.49 & 3.52 & 3.53 & 3.66 \\
\hline India & 3.07 & 3.12 & 3.08 & 3.08 & 3.42 \\
\hline
\end{tabular}

h. Source:https://data.worldbank.org/indicator/LP.LPI.OVRL.XQ?locations=IN-CN

\section{Government policy}

\section{1) Tax policy}

The higher the tax rate, the lower the investor's return on investment in the country. Conversely, the lower the tax rate, the higher the return on investment. In recent years, the proportion of China's total tax revenue to corporate profits is close to $70 \%$, India is only about $55 \%$, and China's tax revenue accounts for a proportion of corporate profits that is nearly $15 \%$ higher than India's, which is unfavorable for China's manufacturing industry's international competitiveness. Because the tax revenue is too high, the profits obtained by the investment will be less, which will reduce the foreign investment in China's manufacturing industry, In terms of tax policy, the Indian government has more favorable policies to promote the development of manufacturing [10].

TABLE VI. TOTAL TAX REVENUE AS A PERCENTAGE OF CORPORATE PROFITS (\%)

\begin{tabular}{|c|c|c|c|c|c|}
\hline & 2013 & 2014 & 2015 & 2016 & 2017 \\
\hline China & 68.8 & 68.6 & 67.9 & 68.2 & 67.3 \\
\hline India & 55.7 & 55.5 & 55.5 & 55.3 & 55.3 \\
\hline
\end{tabular}

\section{2) Medical system}

An efficient medical system provides strong support for a strong and competitive manufacturing system. India's medical expenditure as a share of GDP and per capital medical expenditure are lower than China's. From 2000 to 2015, the share of medical expenditure in GDP in the two countries was small, but due to the large increase in GDP, the amount of medical expenditure has actually increased a lot; the gap in per capital medical expenditure has changed very much. i. Source:https://data.worldbank.org/indicator/IC.TAX.TOTL.CP.ZS?locations=IN-CN Obviously, in 2000, China's per capital medical expenditure was about twice that of India, China's was 42.5 dollars, and India's was 18.56 dollars. From 2000 to 2015, China's per capital medical expenditure rose by nearly 10 times to 425.63 dollars. In the ten years. India's per capital medical expenditure rate of increase has not even reached four times, by 2015 , it was only 63.31 dollars. Even China's 2005 per capital medical expenditure exceeded 75 dollars.

TABLE VII. THE SHARE OF MEDICAL EXPENDITURE IN GDP (\%) AND PER CAPITAL MEDICAL EXPENDITURE (US DOLLAR)

\begin{tabular}{|l|l|l|l|l|c|c|c|}
\hline \multirow{2}{*}{} & \multicolumn{3}{|c|}{$\begin{array}{c}\text { The share of medical } \\
\text { expenditure in GDP (\%) }\end{array}$} & \multicolumn{3}{c|}{ Per capital medical expenditure } \\
(US dollar)
\end{tabular}

\section{SUGGESTIONS FOR IMPROVING THE INTERNATIONAL COMPETITIVENESS OF CHINA'S MANUFACTURING INDUSTRY}

\section{A. Increase investment in education and improve the quality of workers}

First of all, we must increase investment in human capital, especially in rural education, because the important source of labor in China's manufacturing industry is the rural labor force. And raising the level of peasants' education can increase the technical level of the labor force, thereby increasing the production efficiency and improving China's productivity can creates better conditions for manufacturing's international competitiveness.

\section{B. Continue to improve the infrastructure construction and advance the tax system reform}

The backwardness of India's domestic infrastructure is an important reason for the slow development of the manufacturing industry. As a competitor, China should give full play to its advantages in infrastructure and continue to improve its infrastructure construction in backward areas. Secondly, reform of the taxation system will reduce the burden on enterprises. At the same time, the reduction in tax revenue will increase the return on investment, and it will also attract more investment to develop the manufacturing industry [11]. 


\section{Strengthen cooperation with other economies}

China is rich in labor and resources, but it lacks funds and technology is relatively backward. It is just the opposite of developed countries. Cooperation with developed countries, both sides learn from each other and China needs to actively attract foreign investment, and use cooperation opportunities to cultivate talented people, learn advanced technologies, and increase production efficiency [12]. At the same time, it will enhance the links with other economies, establish our own brands, expand sales channels for manufacturing products, and promote the reform and transformation of enterprises.

\section{CONCLUSIONS}

With regard to the factors affecting the international competitiveness of China-India manufacturing, the differences between the two countries in advanced production factors are relatively large, and they are similar in basic production factors. In terms of talent and knowledge resources, capital resources and infrastructure, logistics industry and medical system, China has a comparative advantage over India. However, India's manufacturing industry is also in terms of labor costs, service industry development, and taxation policies has a better development advantage.

\section{REFERENCES}

[1] Chen Wenke. (2013). Analysis of Present Situation and International Competitiveness of Chinese Manufacturing. Foreign Economy and Trade: $7-10$.

[2] M.E.Porter (1990). the competitive advantage of nations[M].MACILLAN PRESS LTD, LONDON,

[3] Dong-Sung Cho (2000). Hwy-Chang Moon from Adam Smith to Michael Porter: evolution of competitiveness theory [J]. World Scientific

[4] Yu Mingyuan. (2016). Analysis of Influencing Factors on International Competitiveness of Chinese Manufacturing Industry. Shan Dong : Shan Dong University

[5] Zhou Luhan. (2016). How India Becomes the Second Largest Manufacturing Power in the World. New Economic Guide Journals: 6065.

[6] Yang Wensheng. (2016). Indian Manufacturing: Competition and Cooperation with China. Import and Export Manager: 47-49.

[7] Li Jianxuan. (2016). Strategic Focus and Policy Analysis of Innovation and Development of Manufacturing Industry in USA Germany and China. China Soft Science: 37-44.

[8] Liao Yi, Lan. (2009). An Empirical Study on the Effects of Intra industry Trade in China's Manufacturing Industry. Exploration of Economic Problems: 1-7.

[9] Li Gang, Dong. (2009). Comparison and Explanation of International Competitiveness between China and India. Contemporary Asia Pacific Economy: 124-148.

[10] Tao Chunmei, Tang. (2016). Research on the Evaluation of Export Competitiveness of Chinese Manufacturing Products. Dongyue Forum: 186-190.

[11] Xu Pengjie (2013). Comparative Analysis on International Competitiveness of BRICS Manufacturing Industry. Fujian Agriculture and Forestry University.

[12] Li Gang (2013) Comparative Analysis of International Competitiveness of Chinese Manufacturing Industry, Dong Bei University of Finance and Economics. 